\title{
Immunological Investigation of Intestinal, Liver, Kidney, Bone, Placental and Serum Alkaline Phosphatase in Cattle
}

\author{
Kiyoshi MIYAZAWA and Isamu TOMODA ${ }^{1)}$ \\ Department of Veterinary Obstetrics and Gynecology, Obihiro University of Agriculture and Veterinary Medicine, \\ Inada-cho, Obihiro, Hokkaido 080, and ${ }^{11}$ Department of Clinical Pathology, Nippon Veterinary and Zootechnical \\ College, 1-7-1 Kyonan-cho, Musashino 180, Japan
}

(Received 2 March 1987/Accepted 10 November 1988)

ABSTRACT. The purpose of this study is to investigate the immunological difference between intestinal, liver, kidney, bone, placental and serum alkaline phosphatases (ALPs) in cattle. Kidney, bone and placental ALPs were purified from each tissue by gel filtration and ion-exchange chromatographies, and intestinal, liver, and placental ALPs were obtained from a commercial source. The antibody to each tissue ALP was prepared by immunizing rabbits and tested by double immunodiffusion analysis in cross reactivities. The results indicated that the bovine tissue ALPs are divided into four groups in antigenicity, that is, intestinal, bone, liver and kidney-placental ALPs. The fetus, calf and cow sera contained bone ALP, and calf and cow sera also contained kidney or placental ALP, but all of the sera did not contain intestinal and liver ALP.-KEY wORDS: alkaline phosphatase isoenzyme, cattle, immunology, serum, tissue.

Jpn. J. Vet. Sci. 51(2): 309-314, 1989

ALP is an enzyme existing in the tissues and body fluids of all vertebrates that hydrolyzes phosphomonoesters [4]. It is well-known that several isoenzymes of ALP are distributed in different tissues with different frequencies $[5,17]$. Differences in the properties of serum and some tissue ALP isoenzymes in cattle have been elucidated by inhibition tests $[7,8]$ and electropholetic analyses[6]. However, little work has been done to study the immunological properties of ALP isoenzymes of cattle [1] and their tissue distribution.

\section{MATERIALS AND METHODS}

Preparation of crude enzyme: All the extraction and purification steps were performed at $4^{\circ} \mathrm{C}$. The techniques used in this study are a modification of those described by Engström [3] and Morton [13]. Kidney and bone samples were collected from a slaughterhouse. One kilogram of kidney tissue was homogenized with 3 liters of 0.01
$M$ sodium acetate- $0.01 \mathrm{M}$ magnesium acetate and centrifuged at $2800 \mathrm{~g}$ for $30 \mathrm{~min}$ : A crude ALP fraction was obtained by successive precipitation with $30 \%$ N-butanol, $50 \%$ acetone, $30 \%$ ethanol and $60 \%$ ethanol. Ossa antebrachii of cow was brayed with a file and a crude fraction was prepared in the same way.

Purification of the enzyme: 1. Chromatography on TEAE-cellulose: The final ethanol fraction of kidney or bone samples, and one gram of crude placental ALP (Sigma Co., Ltd.), were chromatographed on a $50 \mathrm{~m} l$ column of TEAE-cellulose (Serva Feinbiochemica GmbH. \& Co.). Elution was performed with a gradient mixture of $800 \mathrm{~m} l$ of $0.01 \mathrm{M}$ Tris-acetic acid buffer ( $\mathrm{pH} 8.8$ ) containing $0.1 \mathrm{M}$ magnesium acetate. Fractions of $10 \mathrm{~m} l$ were collected every $15 \mathrm{~min}$. The enzyme-active fractions were combined and concentrated to a few milliliters with collodion bag SM13200 (Sartorius $\mathrm{GmbH}$ ) and dialyzed against $0.01 \mathrm{M}$ Tris-acetic acid buffer $(\mathrm{pH}$ 
8.8). 2. Re-chromatography on TEAEcellulose: The enzyme-active fraction was re-chromatographed on TEAE-celluloe, as described above. A gradient mixture was made by mixing $0.01 \mathrm{M}$ Tris-acetic acid buffer $(\mathrm{pH} 8.8)$ and $0.05 \mathrm{M}$ Tris-acetic acid buffer ( $\mathrm{pH} 8.8$ ) containing-0.25 M sodium acetate in the same volumes as described above. The enzyme-active fractions were also concentrated and dialyzed against 0.025 $M$ Tris-acetic acid buffer ( $\mathrm{pH}$ 8.8). 3 . Chromatography on Sephadex G-200: The enzyme-active fraction was finally chromatographed on a $50 \mathrm{ml}$ column of Sephadex G-200 (Serva Feinbiochemica GmbH. \& Co.). Elution was performed with $0.025 \mathrm{M}$ Tris-acetic acid buffer ( $\mathrm{pH} 8.8$ ) containing 1 $\mathrm{M}$ sodium acetate. One or two $\mathrm{m} l$ fractions were collected every $30 \mathrm{~min}$.

Protein determinations: The protein concentration of each fraction was determined by absorbance at $280 \mathrm{~m} \mu$ in a Shimadzu DU spectrophotometer.

Enzyme assays: Enzyme activity was measured by the method of Watanabe [18] (ALP-S Kit, Yatorone).

Preparation of antibody to each tissue isoenzyme: Purified $0.3 \mathrm{mg}$ placental (0.3 $\mathrm{ml}), 0.29 \mathrm{mg}$ bone $(0.25 \mathrm{ml}), 0.44 \mathrm{mg}$ kidney $(0.5 \mathrm{ml})$ ALPs, and $200 \mu \mathrm{g}$ (210 units) commercial intestinal $(0.2 \mathrm{~m} l)$ and $3 \mathrm{mg}$ liver $(0.3 \mathrm{~m} l)$ ALPs, purchased from Sigma Co., Ltd., were diluted to a volume of $1 \mathrm{~m} l$ with Tris-acetic acid buffer $(0.01 \mathrm{M}, \mathrm{pH}$ 8.9). Each antigen preparation $(1 \mathrm{~m} l)$ was emulsified with an equal volume of Freund's complete adjuvant (Difco) and injected subcutaneously into a rabbit 4 times every week. Sera were collected one month after the final injection.

Immunological technique: Ouchterlony's double immunodiffusion tests were performed in $1 \%$ agar gel containing $0.025 \mathrm{M}$ veronal buffer ( $\mathrm{pH} 8.6$ ), allowing the gels to stand for 1 or 2 days at $4^{\circ} \mathrm{C}$. Precipitin lines were stained with amidoblack after soaking the gel in $0.85 \% \mathrm{NaCl}$ solution for 4 days. Positive or negative results were indicated by the respective presence or absence of precipitation lines. Anti-bovine tissue ALP sera and tissue ALP preparations were serially diluted, and each dilution of antiserum was diffused against each dilution of antigen preparation to find their suitable concentrations to give a fine precipitin line. For absorption tests, each antiserum and tissue ALP preparation were mixed in each proper concentration and incubated at $37^{\circ} \mathrm{C}$ for 24 hours. Then the precipitate was removed by centrifugation at $12000 \mathrm{~g}$ and the supernatant was used for the immunodiffusion test.

\section{RESULTS}

Rechromatography using TEAE-cellulose of bone ALP and final gel chromatographs of placental and kidney ALPs are shown in Figs. 1, 2, and 3, respectively. The enzyme activities of the finally purified placenta, bone and kidney were 3.7, 40.0 and $5.3 \mathrm{KAU} / \mathrm{mg} . \mathrm{N}$, respectively. These ALP preparations were used for immunization. The purities of these preparations were demonstrated by a single precipitin line produced against each antiserum in the double diffusion test and by immunoelectrophoretical analyses (data not shown). The precipitin tests are shown in Fig. 4 and the results summerized in Table 1.

Anti-intestinal ALP gave only one clear precipitin line against the homologous ALP (Fig. 4a), and the precipitin was not absorbed with any other tissue ALP preparations (Table 1 ).

Anti-liver ALP gave a precipitin line against liver, kidney and placental ALPs, and the precipitation line against the homologous ALP was partially fused with those against kidney or placental ALP (Fig. 4b). It indicates that liver ALP contains another determinant than those possessed by kidney 


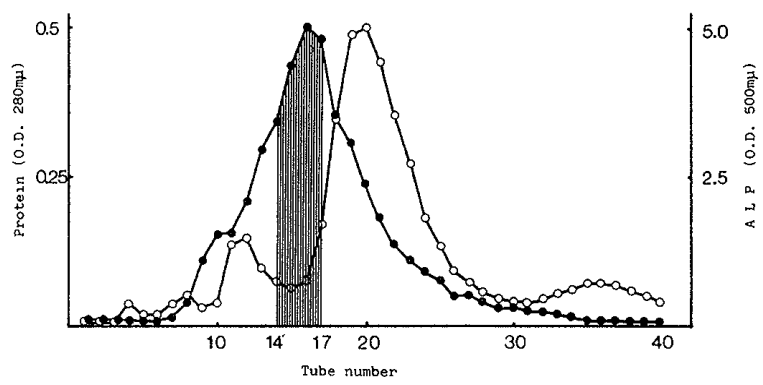

Fig. 1. Re-chromatography of bone alkaline phosphatase on TEAE-cellulose. The enzyme-active fraction $(158.3 \mathrm{mg}$ ) which was obtained by TEAEcellulose chromatography was applied to a $1.6 \times 25 \mathrm{~cm}$ column. Gradient elution was performed as described in Materials and Methods. Fractions 14-17 were pooled and used for immunization. Open circles: Protein concentration (absorbance at $280 \mathrm{~m} \mu$ ). Closed circles: Enzyme activity.

and placental ALPs.

Anti-placental and anti-kidney ALPs gave a fused precipitin line against liver, placental and kidney ALPs (Fig, 4c, 4e), and they also reacted with calf and cow sera but not with fetal sera (Fig. 4f, 4g).

Anti-bone ALP gave a precipitin line against the homologous ALP and the precipitin was not absorbed with any other tissue ALP (Fig. 4d). A fused precipitin line was observed in its reaction with fetal, calf and cow sera (Fig. 4h).

\section{DISCUSSION}

Our results indicating that bovine intestinal ALP has unique immunological properties perfectly coincide with other reports described for intestinal ALP of other species $[14,15,16]$. Healy [7] also reported that only intestinal ALP but not other tissue ALPs from cattle was inactivated by urea and L-phenylalanine. Gahne [6] divided bovine ALP into two groups, intestinal ALP and other organ ALP, by electrophoretical analyses of neuraminidase-treated ALPs. However intestinal and placental ALPs were mutually cross-reactive $[9,10]$, and liver, bone and spleen ALPs were also

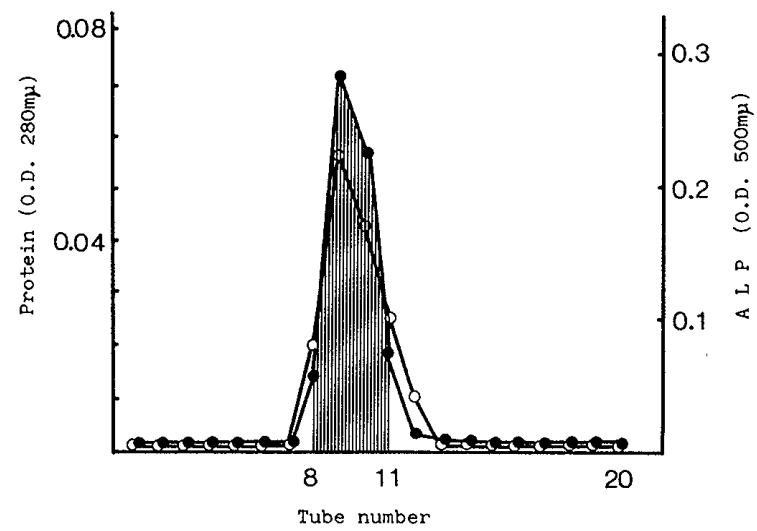

Fig. 2. Re-chromatography of placental alkaline phosphatase on Sephadex G-200. The enzymeactive fraction $(3.0 \mathrm{mg})$ which was obtained by Sephadex G-200 chromatography was applied to a $1.6 \times 25 \mathrm{~cm}$ column. Elution was performed as described in Materials and Methods. Fractions 8-11 were pooled and used for immunization. Symbols are the same as those shown in Fig. 1.

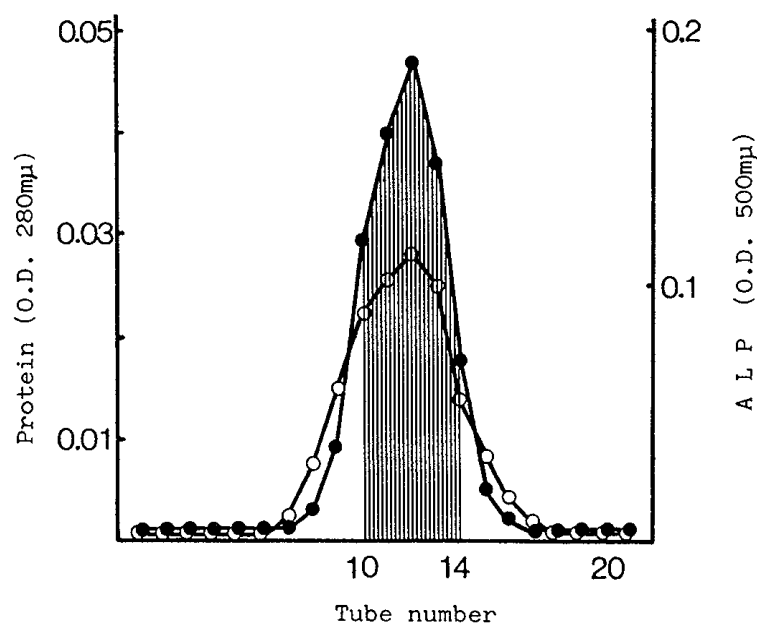

Fig. 3. Re-chromatography of kidney alkaline phosphatase on Sephadex-G200. The enzymeactive fraction $(36.4 \mathrm{mg}$ ) which was obtained by Sephadex G-200 chromatography was applied to a $1.6 \times 25 \mathrm{~cm}$ column. Elution was performed as described in Materials and Methods. Fractions 10-14 were pooled and used for immunization. Symbols are the same as those shown in Fig. 1.

mutually cross-reactive [2]. Saini and Saini [15] reported that bone and liver ALPs from dog were cross-reacting but other tissue ALPs were not cross-reactive. Our finding that cattle bone ALP also possessed a unique antigenicity was not consistent with these reports. The reasons for those contra- 
dictory findings are unknown. The differences in distribution of ALP isoenzymes in different species may depend on differences in the physiological adaptation of each animal.

Calf and cow sera reacted with antiplacental, anti-kidney and anti-bone ALP. As calves and cows were not pregnant, ALP isoenzymes of the sera should be derived from the kidney and the bone tissue. Miyazawa et al. [12] reported that ALP activity of bovine fetal kidney was quite low, but it increased immediately after birth in the epithelial cells of renal tubules. It increases in parallel with development of kidney function [11]. This indicates that elevation of ALP levels in calf and cow sera is related to the functional development of kidney rather than growth of bone tissue.

In the present studies, immunological properties of each ALP isoenzyme from different tissue and serum were examined. In further studies, ALP stain of precipitation lines and comparison with these biochemical properties will be useful.

REFERENCES

1. Arsenis, C., Hacket, M. H., and Huang, S. M. 1976. Resolution, specificity and transphosphorylase activity of calcifing cartilage alkaline phosphatases. Calcif. Tissue Res. 20: 159-171.

2. Boyer, S. H. 1963. Human organ alkaline phos-

Table 1. Ouchterlony's double immunodiffusion analyses of bovine tissue and serum ALPs

\begin{tabular}{|c|c|c|c|c|c|c|c|c|c|c|}
\hline \multirow{2}{*}{$\begin{array}{l}\text { Anti-tissue } \\
\text { ALP }\end{array}$} & \multirow{2}{*}{\multicolumn{2}{|c|}{$\begin{array}{l}\text { Bovine tissue } \\
\text { ALP used for } \\
\text { absorption }\end{array}$}} & \multicolumn{5}{|c|}{ Tissue ALP } & \multicolumn{3}{|c|}{ Serum } \\
\hline & & & I & $\mathrm{L}$ & $\mathrm{K}$ & B & $\mathrm{P}$ & Fetus & Calf & Cow \\
\hline \multirow[t]{5}{*}{ Anti-I ALP } & & & + & - & - & - & - & - & - & - \\
\hline & $\mathrm{L}$ & ALP & + & - & - & - & - & - & - & - \\
\hline & & ALP & + & - & - & - & - & - & - & - \\
\hline & $\mathrm{B}$ & ALP & + & - & - & - & - & - & - & - \\
\hline & $\mathbf{P}$ & ALP & + & - & - & - & - & - & - & - \\
\hline \multirow[t]{5}{*}{ Anti-L ALP } & & & - & + & + & - & + & - & - & - \\
\hline & I & ALP & - & + & + & - & + & - & - & - \\
\hline & & ALP & - & + & - & - & - & - & - & - \\
\hline & B & ALP & - & + & + & - & - & - & - & - \\
\hline & $\mathrm{P}$ & ALP & - & + & - & - & - & - & - & - \\
\hline \multirow[t]{5}{*}{ Anti-K ALP } & & & - & + & + & - & + & - & + & + \\
\hline & I & ALP & - & + & + & - & + & - & + & + \\
\hline & $\mathrm{L}$ & ALP & - & - & + & - & + & - & + & + \\
\hline & B & ALP & - & + & + & - & + & - & + & + \\
\hline & $\mathrm{P}$ & ALP & - & - & - & - & - & - & - & - \\
\hline \multirow[t]{5}{*}{ Anti-B ALP } & & & - & - & - & + & - & + & + & + \\
\hline & I & ALP & - & - & - & + & - & + & + & + \\
\hline & $\mathrm{L}$ & ALP & - & - & - & + & - & + & + & + \\
\hline & $\mathbf{K}$ & ALP & - & - & - & + & - & + & + & + \\
\hline & $\mathrm{P}$ & ALP & - & - & - & + & - & + & + & + \\
\hline \multirow[t]{5}{*}{ Anti-P ALP } & & & - & + & + & - & + & - & + & + \\
\hline & I & ALP & - & + & + & - & + & - & + & + \\
\hline & $\mathrm{L}$ & ALP & - & - & + & - & + & - & + & + \\
\hline & $\mathrm{K}$ & ALP & - & - & - & - & - & - & - & - \\
\hline & $\mathrm{B}$ & ALP & - & + & + & - & + & - & + & + \\
\hline
\end{tabular}

+: precipitation line observed. - : precipitation line not observed.

ALP: alkaline phosphatase. I: intestine. L: liver. K: kidney. B: bone. P: placenta. 

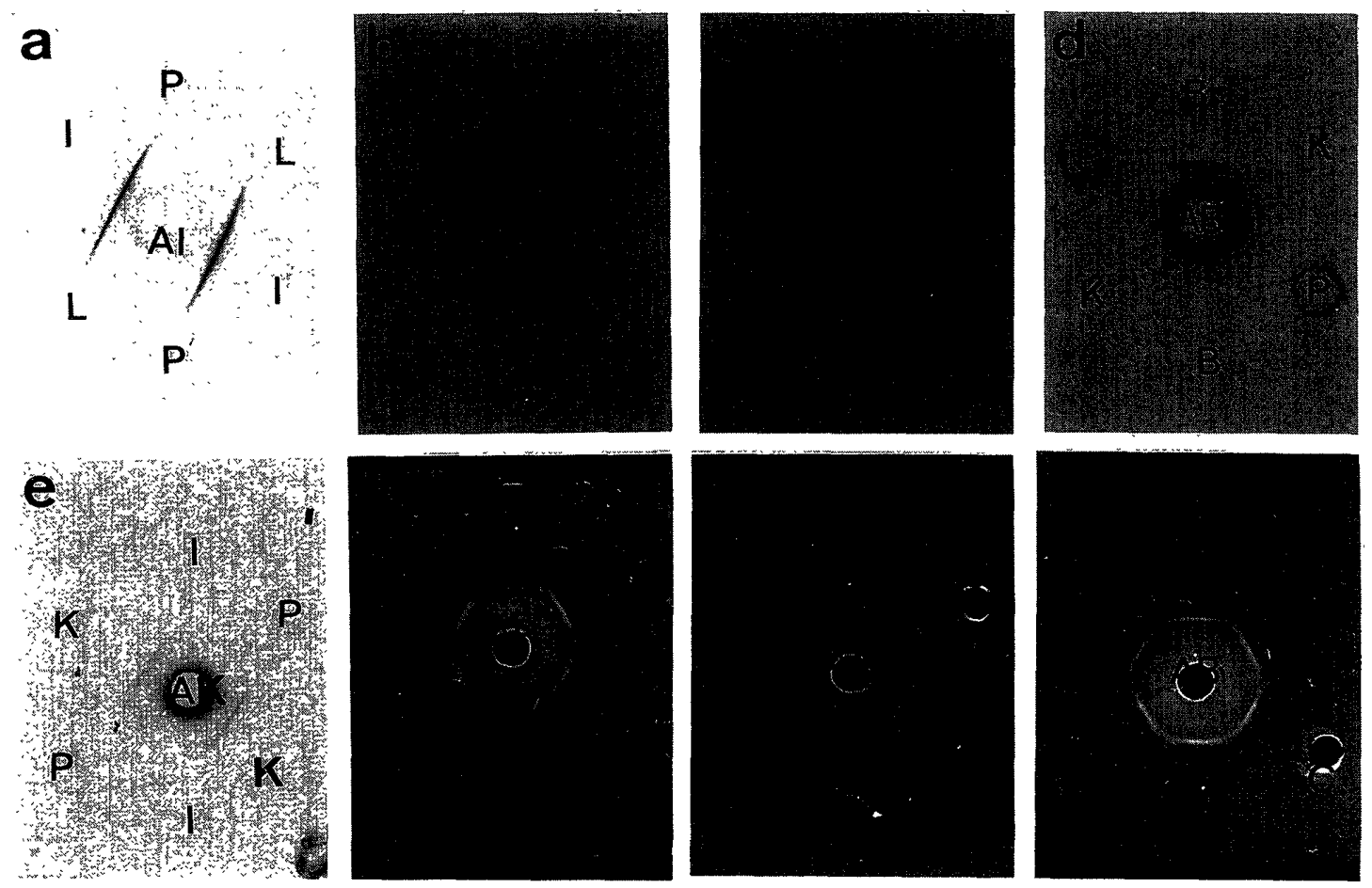

Fig. 4. Double immunodiffusion analysis in agar gel. AI, Anti-intestinal ALP, serum diluted 160 fold (×160); AL, Antiliver ALP $(\times 160)$; AP, Anti-placental ALP $(\times 40) ;$ AB, Anti-bone ALP $(\times 5)$; AK, Anti-kidney ALP $(\times 10)$; I, Intestinal ALP $(0.6 \mu \mathrm{g}) ; \mathrm{L}$, Liver ALP $(12 \mu \mathrm{g}) ; \mathrm{P}$, Placental ALP $(1.2 \mu \mathrm{g}) ; \mathrm{K}$, Kidney ALP $(1.1 \mu \mathrm{g}) ; \mathrm{B}$, Bone ALP $(1.4 \mu \mathrm{g}) ; \mathrm{F}$, Bovine fetal serum at the original concentration $(\times 1)$; $\mathrm{Cf}$, Calf serum $(\times 1)$; C, Cow serum $(\times 1)$; Quantity of each antigen and antibody applied was $0.006 \mathrm{~m} l$.

phatases; Discrimination by several means including starch gel electrophoresis of antienzyme-enzyme supernatant fluids. Ann. NY Acad. Sci. 103: 938-951.

3. Engström, L. 1964. Studies on bovine-liver alkaline phosphatase, purification, phosphate incorporation. Biochim. Biophys. Acta. 92: 71-78.

4. Fernley, H. N. 1971. Mammalian alkaline phosphatase. pp. 417-477. In: The Enzymes vol. 3rd ed. (Boyer, F. D. ed.), Academic Press, New York and London.

5. Froscher, B. G. and Nagode, L. A. 1979. Isoenzymes of equine alkaline phosphatase. Am. J. Vet. Res. 40: 1514-1517.

6. Gahne, B. 1967. Alkaline phosphatase isoenzyme in serum, seminal plasma and tissues of cattle. Herediatas. 57: 100-114.

7. Healy, P. J. 1971. Serum alkaline phosphatase activity in cattle. Clin. Chim. Acta. 33: 423-430.

8. Kolb, E. 1975. Studies on activity and properties of alkaline phosphatase in body fluids (plasma, serum, bile) and in various organs (Kidney, liver, small intestine, bone) in cattle. Arch. Exp. Veterinaermed. 29: 735-758.

9. Lehmann, F. G. 1975. Immunological relationship between human placental and intestinal alkaline phosphatase. Clin. Chim. Acta. 65:
257-269.

10. Lehmann, F. G. 1975. Immunological method for human placental alkaline phosphatase/Regan Isoenzyme/. Clin. Chim. Acta. 65: 271-282.

11. Merlet-Benichou, C., Pegorier, M., Muffat-Joly, M., and Augeron, C. 1981. Functional and morphologic patterns of renal maturation in the developing guinea pig. Am. J. Physiol. 24: F618F624.

12. Miyazawa, K., Tomoda, I., and Usui, K. 1985. A histochemical study of alkaline phosphatase of the kidney in bovine fetuses and calves. Jpn. J. Vet. Sci. 47: 895-900.

13. Morton, R. K. 1954. The purification of alkaline phosphatases of animal tissues. Biochem. J. 57: 595-603.

14. Nisselbaum, J. S., Schlamowiez, M., and Bodans$\mathrm{ky}$, O. 1961. Immunochemical studies of functionally similar enzymes. Ann. New York Acad. Sci. 94: 970-987.

15. Saini, P. K. and Saini, S. K. 1978. Immunochemical study of canine intestinal, hepatic, and osseous alkaline phosphatase. Am. J. Vet. Res. 39: 1506-1509.

16. Schlamovitz, M. 1958. Immunochemical studies on alkaline phosphatase. Ann. New York Acad. Sci. 75: 373-379. 
17. Smith, I., Lightstone, PJ., and Perry, J. D. 1968. Separation of human tissue alkaline phosphatases by electrophoresis on acrylamide disc gels. Clin. Chim. Acta. 19: 499-505.

18. Watanabe, K., Tsuda, T., and Kitamura, M.
1967. A method for the determination of serum alkaline phosphatase-Modification of KindKing's method-. Jap. J. Clin. Path. 15: 708-712 (in Japanese).

要 䄪

ウシ腸, 肝, 腎, 骨, 胎盤ならびに血清アルカリホスファターゼの免疫学的性質: 宮澤清志・友田 勇 ${ }^{1)}$ (带 広畜産大学・11日本獣医畜産大学)一一腎, 骨䇽よび胎盤アルカリホスファターゼ (ALP) は精製したものを, 腸および肝ALPは市販の精製標品を免疫して各蔵器ALP 抗体を作成した。二重免疫拡散法により，各葴器 ALP は免疫学的に腸，骨，肝ならびに腎一胎盤の 4 グループに分類された，骨 ALPは胎児，仔ウシおよび成牛 の血清中に，腎-胎盤ALP は仔ウシおよび成牛の血清中に認められたが腸および肝ALPは，いずれの血清中に も認められなかった。 